\title{
Balancing competitiveness and conditionality: environmental policy- making in low-regulating countries
}

\author{
Christoph Knill, Jale Tosun and Stephan Heichel
}

\begin{abstract}
This article scrutinizes the effects of economic competition on environmental standard levels in low-regulating states that intensify their economic interlinkage with high-regulating countries. In doing so, it pursues two objectives. First, we provide a detailed empirical account of the impact of economic integration on the development of environmental standards in Hungary and Mexico. Second, we offer a theoretical argument in order to explain why low-regulating countries avoid problems of remaining 'stuck at the bottom', although regulatory competition is effective. We argue that missing races to the bottom or stuck at the bottom effects in low-regulating countries are the result of conditionality pressures exerted by high-regulating countries. At the same time, however, low-regulating countries attempt to preserve their comparative advantage 'through the back door' by cultivating a lax enforcement practice.
\end{abstract}

KEY WORDS Conditionality; economic interlinkage; enforcement; low-regulating countries; regulatory competition.

\section{INTRODUCTION}

With increasing economic integration across countries and the emergence of global markets, more attention has been paid to the extent to which domestic regulatory policies are affected by trade relations. Several studies have analysed the relationship between trade liberalization and environmental policy, focusing in particular on the question as to whether industrialized countries face 'environmental dumping'. By contrast, only limited attention has been paid so far to the effects of international economic integration on environmental standards in countries still in the process of industrialization. This paper focuses explicitly on the latter perspective and analyses the effects of economic competition on environmental standard levels in low-regulating states that intensify their economic interlinkage with high-regulating countries.

The distinction between high-regulating and low-regulating countries is based on more recent developments in theories of regulatory competition. 
High-regulating countries generally demonstrate an advanced level of economic development. Their populations give high priority to the quality of the environment. Accordingly, these countries are willing to bear the economic costs of a more ambitious environmental policy. In poorer, less economically developed countries, the quality of the environment is only a secondary priority. The population is less willing to bear the economic costs brought on by strict environmental regulations. These countries prefer environmental regulations at a lower level.

Although hitherto analyses deserve credit for elucidating the nature of the economic sources of environmental regulatory outcomes and the impact of international institutions, they fall short of taking into account the structural differences in the regulatory choices between high- and low-regulating countries. In this regard, Porter (Porter 1999: 134) argues that in the latter group regulatory competition causes a 'stuck at the bottom' effect. This argument, however, is questioned by Vogel (2000) who points out that convincing empirical support for a 'stuck at the bottom' effect is absent.

Against this backdrop, our paper pursues two objectives. First, it provides new empirical evidence in an area which, so far, has not been investigated systematically. We provide a detailed empirical account of the impact of economic integration on the development of environmental standards in Hungary and Mexico. Second, we offer a theoretical argument in order to explain why lowregulating countries avoid problems of remaining stuck at the bottom, although regulatory competition is effective.

In this context, it is important to stress that we are not focusing on the potential effects of legal harmonization; i.e. the definition of binding standards at the level of international or supranational organizations in order to establish a 'level playing field' for economic competition. In such cases, the absence of races to the bottom is indeed trivial. We focus rather on constellations in which potential effects of environmental dumping through regulatory competition are not excluded by the definition of harmonized standards at the international level.

We argue that missing races to the bottom or stuck at the bottom effects in low-regulating countries is the result of conditionality pressures exerted by highregulating countries. Low-regulating countries face a trade-off between strengthening their standards in exchange for intensified trade relations and leaving their standards at the bottom in order to preserve the international competitiveness of domestic industries in the integrated market. To resolve this conflict, lowregulating countries introduce advanced environmental standards, mainly through emulating the policies of countries that they perceive as being economically successful or to which they are closely linked (in terms of geography or culture). At the same time, however, low-regulating countries attempt to preserve their comparative advantage 'through the back door' by cultivating a lax enforcement practice.

To illustrate our theoretical argument, we present a comparative case study analysis on the evolution of environmental process standards, namely limit values for industrial discharges into national surface waters, in Hungary and 
Mexico. The case studies are based primarily on semi-standardized interviews with politicians, administrative officials, scientific experts as well as representatives from industry and environmental associations in both countries. ${ }^{1}$

\section{THEORETICAL ARGUMENT: TRADE-OFFS BETWEEN REGULATORY COMPETITION AND POLITICAL CONDITIONALITY}

\subsection{Effects of regulatory competition: stuck at the bottom?}

The central mechanism through which economic integration may influence national environmental policies is regulatory competition between nation states. With the increasing integration of global markets, the international mobility of goods, workers and capital puts pressure on the nation states to redesign domestic market regulations in order to avoid regulatory burdens restricting the competitiveness of domestic economic actors, mostly industries. Yet, the concept of regulatory competition does not allow for simple conclusions. The most prominent hypothesis on the effects of regulatory competition is that it entails a race to the bottom. There is, however, a striking lack of empirical support for this prediction. In fact, there is case study evidence for the occurrence of the complete opposite; i.e. a race to the top (see Jänicke 1998; Kern 2000; Vogel 2000).

To account for this development, a number of propositions were specified for predicting the direction of change stimulated by regulatory competition. The most common approach is a distinction between product and process standards. Process standards imply restrictions on the use of specific inputs or specify requirements, technologies or processes for industries. Product standards, by contrast, refer to technical specifications for a certain product.

In the case of process standards, we find a widely shared expectation that policy convergence will occur at the lowest common denominator; states will gravitate towards the policies of the most laissez-faire country. If the regulation of production processes implies an increase in the costs of production, potentially endangering the international competitiveness of an industry, regulatory competition will generally exert downward pressures on economic regulations (Holzinger and Knill 2005; Murphy 2004). It is assumed that governments are ready to lower environmental standards in the face of lobbying and exit threats exerted by the respective industry.

Expectations are less homogeneous for product standards. While industries in both low-regulating and high-regulating countries have a common interest in harmonizing product standards to avoid market segmentation, the level of harmonization can hardly be predicted without examination of additional factors. Most important in this context is the extent to which high-regulating countries are able to factually enforce stricter standards. If it is possible to erect exceptional trade barriers, as for example for health or environmental reasons under the rules of the European Union (EU) or World Trade Organization, convergence at a 
high level of regulation is to be expected. If such exceptional trade barriers cannot be justified, by contrast, competitive pressure will induce governments to lower their standards (Holzinger and Knill 2005).

Further, it is argued that the empirical absence of races to the bottom is caused by the fact that regulatory competition may be overlapped by other mechanisms affecting the adjustment of national policies, in particular regulatory co-operation at the supranational or international level (Esty and Geradin 2001). To avoid downward pressures on environmental standards emerging from trade liberalization, the involved countries agree on common legally binding environmental standards through international harmonization.

In sum, this theoretical discussion provides us with clear expectations with respect to the cases under study. The fact that we deal with regulatory standards that are not subject to international harmonization, and refer to process rather than production processes, provides an almost ideal case, in which a stuck to the bottom effect is highly conceivable. This expectation is further enhanced by the fact that for low-regulating countries we can assume weak domestic demand for stricter environmental regulation. This suggests the following hypothesis:

H1 (Isolated effect of regulatory competition): The more countries with low environmental process standards face competitive pressures emerging from international economic integration, the more they prefer to keep these standards at a lower level than their high-regulating trading partners.

\subsection{Effects of political conditionality: race to the top?}

Inherent to theories of regulatory competition is the assumption that the involved countries are rather autonomous in adjusting their regulations for enhancing their competitiveness. This way, however, potential power asymmetries between the involved countries are not sufficiently taken into account (Drezner 2005). The latter emerge in particular if the benefits of intensified trade relations are distributed unevenly among the trading partners.

This constellation is likely if low-regulating countries aim at integrating their economies with high-regulating countries which possess more advanced regulatory systems. Given their weak economic position and the - compared to high-regulating countries - much higher relative welfare gains associated with economic integration, low-regulating countries are generally more dependent on intensified trade relations than their more wealthy counterparts. This holds true in particular if the latter already have well-established free trade regimes with each other (such as the North American Free Trade Agreement (NAFTA) or the EU 15).

Depending on the degree of these resource dependencies, high-regulating countries are hence able to render further economic integration with lowregulating countries subject to conditionality prior to the conclusion of a free trade agreement. To protect the competitive position of their economies, they can factually impose the adoption of stricter regulatory standards in 
low-regulating countries in exchange for intensified trade relationships. In other words, there is an exchange of economic resources for the adoption of stricter environmental policies. Thus, conditionality constitutes incentives for lowregulating countries to adjust their regulatory arrangements in order to qualify for belonging to the group of the other members forming the international trade regime; i.e. market access can function as an important instrument to encourage sound environmental standards. There are two typical cases of such conditionality pressures: the unilateral imposition of a policy on a country by another country, and conditionality by an international institution or trade regime (Holzinger and Knill 2005).

Based on these considerations, we expect that low-regulating countries adopt the regulatory standards of their high-regulating trading partners on which they are most dependent. As emphasized by DiMaggio and Powell (1991: 67), dependent organizations are likely to adopt patterns of behaviour sanctioned by organizations that control critical resources. Conditionality pressures can thus be understood as homogeneity forces stemming from political influence.

H2 (Isolated effect of political conditionality): The more countries with low environmental process standards face conditionality pressures from their trading partners, the more they adjust their standards to the level of these countries.

\subsection{Balancing the trade-offs between competitiveness and conditionality}

Regulatory competition and political conditionality confront low-regulating countries with a trade-off constellation. On the one hand, they can achieve important welfare gains by intensifying their trade relations with high-regulating countries. To obtain these gains, they are required to adjust their regulatory standards. On the other hand, by taking account of the structural differences between industrialized and industrializing countries, we should not overlook the fact that the costs of improving the environmental regulatory systems can substantively burden the latter, hence reducing their economic competitiveness. These challenges emerge in particular for small and medium-sized domestic companies which generally suffer from low productivity rates (Dasgupta et al. 2000). How can industrializing states balance incentives to keep weak environmental standards emerging from regulatory competition and enticements to raise these standards in exchange for further economic integration?

To answer this question, we apply a more differentiated perspective on the effects of regulatory competition that encompasses not only a focus on regulatory outputs (the formal level of environmental standards), but also on the extent to which these standards are actually implemented and complied with.

By assuming strategic behaviour, we expect low-regulating countries to balance contradictory pressures emerging from concerns about international competitiveness and conditionality pressures by combining stricter standards with lax implementation. On the one hand (and in line with hypothesis 2), low-regulating 
countries adopt tight environmental standards, typically emulating corresponding arrangements of their most important trading partners in order to secure access to international markets. On the other hand, they respond to competitive pressures 'through the back door' by ineffective implementation of the strict requirements. Or in other words, they still engage in regulatory competition, but instead of regulatory behaviour they do it by enforcement behaviour. One could certainly argue that enforcement deficits are less the result of the strategic behaviour of governments than of lax administrative monitoring and control capacities. Our argument is not meant to contradict this latter view. Rather, we assume that lack of attempts to build up administrative capacities can be interpreted as strategic neglect of requirements for effective compliance.

This strategy should be intuitive as possible adjustment costs for lowregulating countries will not emerge during policy formulation but rather during enforcement owing to insufficient institutional capacities of local environmental agencies in terms of staffing and funding. This implies that low-regulating states engage in regulatory competition in environmental regulation through their enforcement behaviour rather than their regulatory output in terms of standard levels.

H3 (Interaction effects of regulatory competition and conditionality): If countries with low environmental process standards face both conditionality pressures from their trading partners and competitive pressures emerging from international economic integration, the expected response pattern is a combination of stricter environmental standards (in response to conditionality) and lax implementation (in response to regulatory competition). The effects of regulatory competition hence become apparent with regard to implementation rather than regulatory output.

\section{EMPIRICAL EVIDENCE: ENVIRONMENTAL POLICY IN HUNGARY AND MEXICO}

We illustrate our considerations by analysing the development of environmental standards in Hungary and Mexico. With regard to the concrete policy items in question, our focus is on the development of four emission limit values for industrial discharges into water; namely, for emissions of chromium, copper, lead and zinc.

We selected these policies for several reasons. While heavy metals emitted into bodies of water have serious impacts on human health and the general natural equilibrium, and hence are of considerable political salience, the central rationale behind choosing these items is that they constitute standards affecting the process of industrial production. For process standards, theories of regulatory competition generally offer a clear prediction; namely, that growing competitive pressures imply a conservation of lax environmental standards in low-regulating countries. This is assumed to be caused by a probable increase in production costs as tightening standards require investment in 
cleaner technologies. Consequently, pollution-intensive sectors may be confronted with competitiveness risks (Richardson 1995: 165). Moreover, the selection of these items has the additional advantage that 'disturbing' effects of international harmonization - which might potentially interfere with the effects of regulatory competition - are absent. Neither at the level of the EU nor at the level of NAFTA or any other international organization have concrete legally binding standards with regard to the selected policy items been adopted so far.

As regards the selection of countries, we follow the logic of the most different systems design (Przeworski and Teune 1970). Hungary and Mexico display farreaching differences with regard to many characteristics, including language, socio-economic conditions, legal and administrative traditions, political and historical development as well as the institutional configuration of the political and administrative system. At the same time, however, both countries display important similarities with regard to the variables expected to be of crucial explanatory power in order to account for the balance between competition and conditionality. Both countries show similar patterns in terms of their growing integration into international markets, including the accession to international or supranational trade regimes.

One could certainly argue that the implications of NAFTA and the EU for environmental policies are too distinct from each other, and thus hardly allow for comparison. For instance, compared to the EU, NAFTA institutions have substantially less authority to harmonize regulatory standards. However, we claim that this criticism can be overcome on the basis of our case selection. As the policy items selected are not harmonized at the EU or NAFTA level, differences with regard to the regulatory and enforcement capacities of these organizations should not play a central role in our context.

\subsection{Case study on Mexico}

Three stages can be distinguished in the development of Mexican water standards. During the first two stages, we see the adoption of strict international and particularly US standards. These standards, however, were of limited practical relevance, as they covered only a limited range of industrial sectors and were hardly enforced. During the final stage, this general trade-off between strict standards and weak implementation changed to some extent. With regard to regulatory requirements, an ambiguity can be observed: while the coverage of the regulatory requirements increased, the limit values were partially relaxed. This development coincides, however, with considerable efforts to improve the implementation effectiveness of the standards. Yet, these efforts varied among large (predominantly multinational) and less competitive domestic companies.

Table 1 summarizes the evolution of the limit values at the three stages by showing the range for the four heavy metals selected. We also include the number of industry sectors regulated by the single standards, the strength of 
Table 1 Mexican limit values (in milligrams per litre) given in daily average concentrations

\begin{tabular}{lllllllrr}
\hline & Lead & Copper & Chromium & Zinc & Coverage & Regulatory arrangement & Obligation Relevance \\
\hline $\mathbf{1 9 8 8 - 1 9 9 2}$ & $0.1-5$ & $0.5-1$ & $0.5-5$ & $0.5-10$ & $2-5$ sectors & weak & loose & none \\
1993-1996 & $0.2-0.6$ & $0.5-1$ & 1 & 1 & $5-8$ sectors & weak & yes & none \\
1997 to today & $0.4-1$ & 6 & $1-1.5$ & 20 & all sectors & strengthening & yes & increasing \\
\hline
\end{tabular}

Source: Based on NTE-CCA-001/88 to NTE-CCA-033/91, NOM-CCA-001-ECOL/1993 to NOM-CCA-073-ECOL/1994, and NOM-001SEMARNAT-1996. 
the corresponding regulatory arrangements, as well as the degree of legal obligation and practical relevance of the standards.

Stage 1: Symbolic standards in exchange for economic co-operation

The introduction of the Mexican effluent standards began with the adoption of the General Law of Ecological Equilibrium and Protection of the Environment (Spanish acronym: LGEEPA) in 1988, which represents Mexico's first comprehensive environmental framework law to systematically address a broad range of environmental matters, including water contamination. In accordance with LGEEPA, the Secretariat of Ecology and Urban Development (SEDUE) issued from 1988 onwards 33 industry-specific effluent standards, defining the limit values for the discharges of the most polluting industry sectors. These limit values were basically copied from international regulations, mainly from the US Code of Federal Regulations of the US Environmental Protection Agency (interviews M10; M9). However, the efficacy of these first standards can be questioned. According to an interviewee at the Mexican Water Technology Institute (interview M7), there was uncertainty within SEDUE about which units would be in charge of monitoring and enforcing the implementation of the standards. As a consequence, implementation and enforcement occurred at best in an ad hoc manner. Further, the legislation did not even see a non-compliance charge until 1991 (see also Husted and Logsdon 1997: 33). In sum, we argue that it is not too risky to conclude that the introduction of the limits values in 1988 was primarily a symbolic act, without any recognizable intention of effectiveness.

How can this development be explained? Notwithstanding domestic concerns (albeit still weak) over environmental quality and public health (interview M8), the central driving force has to be seen in the economic reforms that took place from the mid-1980s onwards (interview M4). This development coincided with far-reaching economic reforms from the mid-1980s, which 'transformed a nearly closed economy into one that is highly open to foreign participation in trade and investment' (Máttar et al. 2002: 6).

Therefore, the US has always been the key trading partner (see Figure 1), which explains the Mexican government's strong desire to join NAFTA for indemnifying access to the US market (OECD 1992: 223). In fact in $1989-$ before concluding NAFTA - Mexico and the US signed a framework agreement to facilitate trade and investment between the two countries.

In addition, the US is an important source of foreign direct investment (FDI) in Mexico (see Figure 2). The country benefited from the highest net inflows of FDI among Latin America's largest economies during the 1990s, which favoured the emergence of a dual economic structure. This duality implies the presence of a modern sector with relatively few large, highly competitive and mainly multinational companies, which exists along with numerous small to medium-sized domestic companies that account for 92 per cent of the overall industry (OECD 1998: 72). 


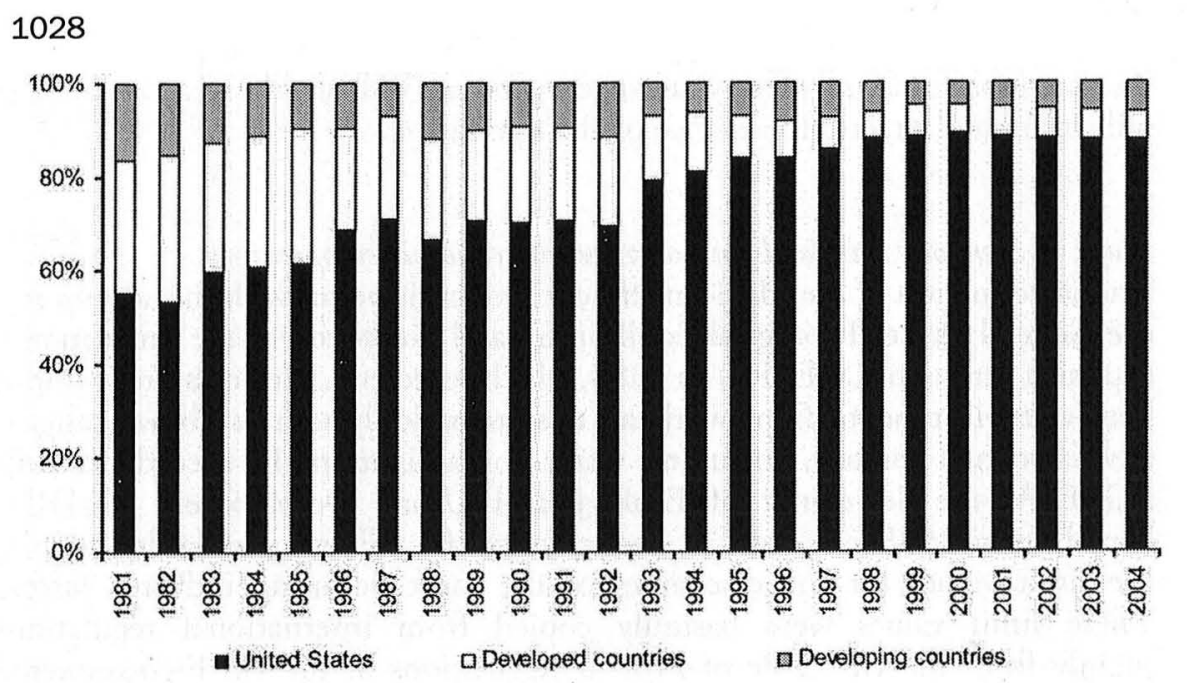

Figure 1 The direction of Mexican exports, 1980-2004 (in millions of US\$) Source: Based on data from International Monetary Fund (2005).

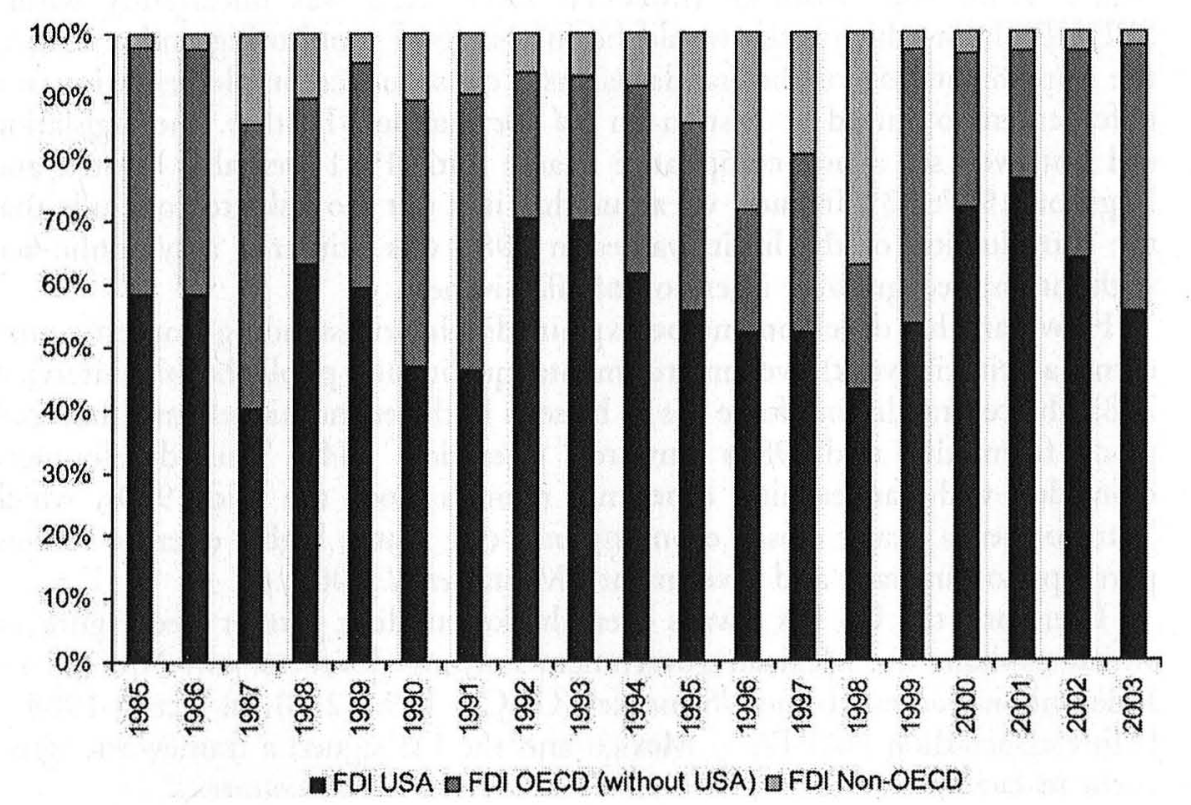

Figure 2 Foreign direct investment, 1985-2003

Source: Based on data from OECD International Direct Investment Statistics Yearbook (2004).

Since both economic indicators - i.e. direction of exports and origin of FDI stress the relative dependency of the Mexican economy, it can validly be argued that the US has had the potential to exert conditionality pressures in order to achieve a co-ordination of environmental standards at its preferred level 
(Drezner 2005: 86f.). In view of this, it is hardly surprising that the establishment of the effluent standards can be explained by Mexico's economic interlinkage with the US (interviews M3; M5; M4; M9). As US environmental non-governmental organizations (ENGOs) and politicians expressed their concerns about industrial relocation, the Mexican government decided to improve its environmental image. To this end, it overhauled the entire environmental legislation and introduced US-style regulation (Rueda 2000: 678).

The commercial relations with our neighbouring countries that emerged through the signing of free trade agreements gave us the impetus to become environmentally competitive. The investments in Mexico needed to consider the spending on environmental protection in order to create a legal competition at the investment market between Canada, the United States, and Mexico.

(interview M4)

Thus, it is fair to reason that the first effluent standards were introduced because of this 'political' motivation. However, we cannot dismiss the fact that public health concerns were also of a certain importance (interview M8). Nonetheless, civic actors, such as Mexican ENGOs, did not play a significant role in the policy-making process. "The policy formulation was realized in a top-down manner. [Mexican] ENGOs hardly participated in the process. [Mexican] ENGOs in general have no considerable weight in environmental policy-making; maybe only Greenpeace' (interview M5; see also Auer 2001: 451). At the same time, this top-down approach indicates that the priority of the Mexican government were regulatory outputs, while aspects of implementation and compliance were mostly neglected (OECD 1998: 117).

\section{Stage 2: Regulatory expansion and persistent non-implementation}

This trade-environment nexus becomes even more apparent in the second regulatory stage, starting in 1993 . While standard levels were not strengthened substantially; the regulatory range was strongly expanded to 11 additional industry sectors. These adjustments were triggered by a new dynamic in the political struggles over Mexican environmental legislation since the US Congress threatened to abort the NAFTA project on environmental grounds.

In fact, a heated debate arose in the US about the environmental effects of enhanced trade and economic activities in the three NAFTA countries (interview M8). The US ENGOs expressed their concerns regarding the environmental effects of intensified trade with Mexico, to which members of the US Congress responded positively. In consequence, before concluding NAFTA, Mexico was politically pressured to sign NAFTA's environmental side agreement and to enact US-style environmental regulations (Mall 1998: 168; interviews M5; M8). The US negotiation style, moreover, reflected the asymmetry of power between the two countries since the environmental concessions were presented as non-negotiable requirements, to which Mexico only reluctantly conceded (Araya 2002: 63f.). Therefore, the revision of the effluent standards as 
a constituent of the general environmental reform package can be judged to have been triggered by conditionality.

A result of this 'forced' policy change was the adoption of again primarily symbolic standards that were 'based on political reasons rather than a scientific or logical reasoning' (Jiménez et al. 1999: 170). But the elaborated regulatory scheme turned out to be unworkable, given the economic and technological situation of the country. 'The authorities set standards without paying attention to geographical particularities or the economic situation' (interview M10). Further, the design of the standards proved to be an impediment to proper implementation. According to the National Water Commission (CNA), the monitoring of the source-specific standards proved to be time-consuming and staff-intensive which, in combination with the chronic resource shortage, led to insufficient enforcement (interviews M3; M6; M7).

\section{Stage 3: Regulatory adjustments and differentiated implementation}

The third stage of the policy evolution started in 1996, when a major reorganization of the waste water regulation was adopted. This development implied important changes with regard to the strictness of regulatory requirements. With the replacement of the previous approach of 44 sourcespecific limit values by an integrated regulatory scheme (embodied by standard NOM-001-SEMARNAT-1996), ${ }^{2}$ the coverage of the regulations was expanded to all industrial sectors. Similar limit values for discharges of all industrial activities were established, with conditions as to the subsequent use of the water and the type of receiving water body (OECD 1998: 64).

Despite recent progress, however, there is still a discrepancy between the rigid standards on the books and their lax enforcement (Rueda 2000: 679; interviews M1; M5; M8). Though enforcement problems mainly result from inadequate funding or staffing deficiencies (interview M3), there is also a more strategic dimension to the monitoring and enforcement activities. This implies that the CNA - in light of its lack of financial resources and weak infrastructure concentrates its monitoring activities on 'suspect' dischargers.

The monitoring agencies seem to put their resources on the 'bad guys'. If you are not a bad guy, they will not detect you. So, there are a lot of small violations that can go through, and that is what I call lax enforcement.

(interview M1)

In fact, this eye on 'suspect' dischargers also means that, primarily, large multinational companies are inspected, while small and medium-sized domestic companies are often spared (interview M5; OECD 1998: 126). However, compliance is less challenging for multinational companies since they usually have modern production technologies and abundant resources (Dasgupta et al. 2000: 61f.). This does not mean that large polluters are always in compliance (Tortajada 2003: 28), but they are generally more attentive. 
Many multinationals are pretty aware that they are being looked at very carefully all over the world. And many of them have developed internal corporate standards of conduct and compliance. And they basically apply those standards to their foreign operations, no matter where they are.

(interview M1; see also interviews M2; M4; M5; M9)

By contrast, compliance has been deficient in small and medium-sized Mexican enterprises as they have neither sufficient knowledge nor funding to undertake effective pollution control measures (interviews M2; M10). Moreover, if these companies co-operate with the monitoring agency, they have few inspections and their discharge documentations are evaluated without any scepticism (interview M1). In 2001, a federal decree provided an amnesty for waste water dischargers who violated the legislation, which predominantly benefited water utilities, municipal and state governments, and industry involved in waste water management (Tortajada 2003: 28). In sum, we interpret these signs of a 'differential' approach towards monitoring and enforcement as a confirmation of hypothesis 3.

A further characteristic of the new system is that, compared to the previous approach, the level of standards was partially relaxed. In contrast to the two former stages, the integrated standards were not simply copied from (though surely inspired by) international regulations, but designed by a national consultative committee, in which members from both the public and the private sector participated. Therefore, the main interest of the committee was in creating a feasible standard which defined 'realistic' limit values (interviews M3; M5) in terms of practical implementation. While the success of this strategy is still doubtful, this development nevertheless reflects a somewhat opposite scenario, in which regulatory adjustments and less stringent standards are combined with efforts to improve the implementation effectiveness of these arrangements. This pattern is still well in line with our general expectations regarding the tradeoff between strictness of regulation and implementation effectiveness, albeit trade-offs are balanced in a different way than expected from the outset.

Several reasons account for this deviation. First, the final revision of the effluent standards occurred after the adoption of NAFTA, when political pressure was considerably relaxed. Second, the notable trend towards better enforcement can be attributed to growing public demand for improvément in environmental quality and the increasing responsiveness of the Mexican authorities to these demands (interview M8). In fact, the environmental institutions created by NAFTA provide leverage to Mexican ENGOs when it comes to influencing and enforcing national environmental regulations (Auer 2001: 443; interview M1). Thus, in the absence of NAFTA, Mexico might not have had sufficient incentives to strengthen its enforcement capabilities (Rueda 2000: 681).

In conclusion, it seems unlikely that the introduction and revision of the effluent standards in the late 1980s and early 1990s would have occurred in the absence of political pressures from the US. Consequently, the first two stages of the policy development can be regarded as a strategy to reduce political 
pressure through introducing largely symbolic legislation. In terms of our hypotheses, this means that regulatory competition was overlapped by conditionality, supporting hypothesis 2 but not hypothesis 1 . The developments during the final stage, by contrast, can be interpreted as confirmation of the expected trade-off between strictness of standards and implementation effectiveness, as stated in hypothesis 3.

\subsection{Case study on Hungary}

With regard to Hungarian water standards, different stages of policy evolution can also be identified. In contrast to Mexico, Hungary had already adopted albeit hardly realistically-ambitious environmental standards during the socialist era (stage 1). The second stage of policy development is characterized by the growing economic integration of the country after regime transition. During this phase, we can clearly observe a de facto 'stuck at the bottom' pattern triggered by regulatory competition. During the final stage that began with the accession of the country to the EU, we observe a further strengthening of regulatory requirements combined with informal patterns of differentiated implementation, implying that standards are enforced much more strictly for large multinational companies than for smaller firms operating within the domestic market. All these developments are well in line with our theoretical expectations.

\section{Stage 1: Symbolic standards}

Long before regime transition and EU accession, Hungary had a regulatory scheme for coping with water pollution caused by industrial discharges. From the 1950 s onwards, numerous regulations were passed, leading to a first consolidated scheme in 1969. Two major revisions followed in 1978 and 1984. The regulations established fines for industrial polluters, levied on the limit value exceeding concentration of polluting substances in the waste water stream. Nationwide uniform limit values for over 30 parameters, including heavy metals, were fixed and later stratified according to the receiving water body's economic and environmental importance (Table 2).

This surprisingly early introduction can be attributed to the power of a wellestablished separate water management sector, which was reinforced during the state socialist regime. Anchored in the structures of the ruling communist party and government, the powerful and financially and technically well-endowed ministry-like National Water Authority accomplished comparatively modern environmental regulations for water protection (Enyedi and Szirmai 1998; interviews $\mathrm{H} 1$; $\mathrm{H} 5$ ).

During the state socialist era, however, the schemes proved to be completely inappropriate for achieving pollution containment. The standards looked impressive on paper and became, after a 1984 decree, formally much stricter than those of Western environmentally progressive countries (Table 2). However, a closer look reveals that the regulations constituted a merely symbolic 
Table 2 Hungarian limit values for four heavy metals in industrial discharges

\begin{tabular}{|c|c|c|c|c|c|c|c|c|}
\hline & Lead & Copper & Chromium & Zinc & Coverage & $\begin{array}{l}\text { Regulatory } \\
\text { arrangement }\end{array}$ & Obligation & Relevance \\
\hline $1990(1984)$ & $0.05-0.2$ & $0.5-2$ & $0.2-1$ & $1-5$ & all sectors & weak & loose & none \\
\hline $\begin{array}{c}2001 / 2004 \\
\text { general }\end{array}$ & $0.05-0.2$ & $0.5-2$ & $0.2-1$ & $1-5$ & $\begin{array}{l}\text { all sectors/ } \\
\text { general }\end{array}$ & $\begin{array}{l}\text { strengthening (BAT } \\
\text { requirement) }\end{array}$ & yes & increasing \\
\hline $\begin{array}{l}2001 / 2004 \\
\text { sector specific }\end{array}$ & $0.04-1$ & $0.1-2$ & $0.1-2$ & $0.5-10$ & $\begin{array}{l}40 \text { specified } \\
\text { sectors }\end{array}$ & $\begin{array}{l}\text { strengthening } \\
\text { (BAT } \\
\text { requirement) }\end{array}$ & $\begin{array}{l}\text { yes (ceasing } \\
\text { pollution } \\
\text { required) }\end{array}$ & increasing \\
\hline
\end{tabular}

Source: Based on Decrees 3/1984 NWA (National Water Authority), 203/2001, 9/2001 MoE/MoTW (Ministry of the Environment/ Ministry of Transport and Water), 220/2004 and 28/2004 MoEW (Ministry of the Environment and Water). 
policy without an intention of being effective. First, waste water standards were not mandatory in a legal sense (interview $\mathrm{H} 2$ ). Rather, exceeding the standards merely obliged polluters to pay relatively mild fines. These low fines, and the lack of power for water authorities to suspend industrial activity when pollution limits were exceeded, did not provide incentives for state enterprises to comply (interviews $\mathrm{H} 1 ; \mathrm{H} 2, \mathrm{H} 4 ; \mathrm{H} 5$ ); 'to pay the fines was much ... cheaper' (interview $\mathrm{H1}$ ). Second, the system relied on self-monitoring of state enterprises and was hence highly susceptible to fraud. Third, effective policy implementation was hindered by the state élite's economic interests, as the owner of the (polluting) enterprises was the state - the regulator and regulated were hence one and the same (interviews $\mathrm{H} 1 ; \mathrm{H} 4)$. 'The economic lobbies, but rather the political lobbies were ... [much] stronger ... than water quality protection [interests]' (interview $\mathrm{H} 1$ ).

The development resembles the general weaknesses of environmental policy in Central and East European states during communist rule (Scheierling 1998). Consequently, the quality of Hungarian surface water increasingly deteriorated from the 1960s to the late 1980s, largely owing to industrial discharges (Hock and Somlyódy 1989).

\section{Stage 2: 'Stuck at the bottom' as a result of regulatory competition}

The second stage of policy evolution refers to the period between regime transition in 1989/90 and the country's application status for EU membership in 1998. During this period, no substantial policy changes occurred ("not much happened between 1984 and 2001'; interview H2), hence implying that Hungary - notwithstanding its strict standards on paper - remained 'stuck at the bottom' with regard to its regulation of water discharges. Fines for exceeding limits, although doubled in 1993, remained too low to become an efficient means of pollution reduction (interview H1). Moreover, whatever its threat had been in the past, inflation made the instrument totally toothless. Most still stateowned or newly privatized enterprises therefore chose to continue paying fines (interviews $\mathrm{H} 1 ; \mathrm{H} 5)$. In general, enforcement of environmental regulation (including waste water standards) in the 1990s was a complete failure.

There is evidence that this striking pattern was a result of the competitive pressures emerging from the growing integration of the Hungarian economy in international markets. The regime transition boosted competitive dynamics as the Hungarian governments opted for an open market economy with strong trade orientation towards the West, notably the EU, combined with an emphasis on attracting foreign capital. In 1991 a so-called European Agreement with the Community established several tariff reductions for access to the common market. Hungary's new economic development strategy became complemented by the (central) European Free Trade Area (Andor 2000: 118).

As Figure 3 indicates, this triggered a steady growth of exports, with the EU emerging as the major trading partner in the 1990s (World Bank 1999: 59ff.). Hungarian exports to EU countries amounted to 50 per cent in 1991, and have surpassed 70 per cent since 1997 . Of particular relevance in our context is the 


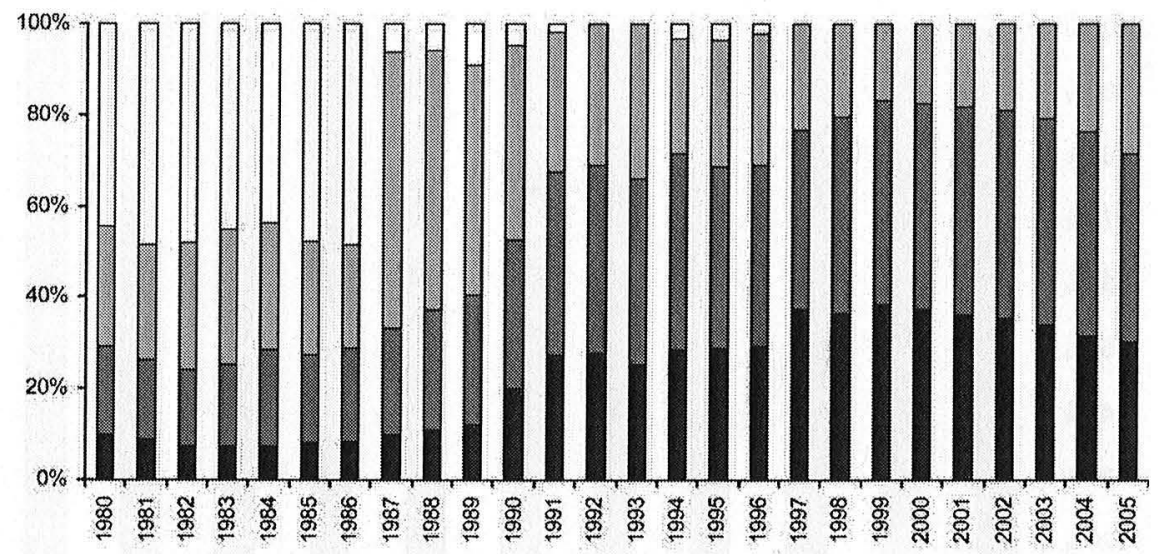

- Germany Developed countries Developing countries bother countries

Figure 3 The direction of Hungarian exports 1980-2005 (in millions of US\$) Source: Based on data from International Monetary Fund (2005).

fact that, between 1993 and 2002, Hungary received around two billion US dollars of foreign investments per year, equalling 5 per cent of the country's gross domestic product (GDP) (OECD 2004: 26; see Figure 4). These figures were by far the highest when compared to the other transformation countries in the region (Andor 2000: 81ff.). Hence, the country's accession to the EU in May 2004 was in economic terms merely the capstone to a drawnout process of wide-ranging reforms and international orientation.

There are clear hints that the low level of enforcement was indeed utilized by some foreign investors who simply acquired domestic state enterprises, kept production going but failed to invest in newer and cleaner technology, without making particular efforts to improve the environmental performance of the company through other investments (interviews H3; H5). Sometimes even large international investors attempted to reach agreements with the environmental authorities on the application of less stringent environmental standards; 'they were not ready to enforce [them]' (interview H5; see also interview H4).

Firms from Western Europe tried to get some [regulatory] advantages. In a lot of cases [the low enforcement level] was the main reason to change ... the production place [from Western Europe to Hungary].

(interview $\mathrm{H} 1$ )

Apparently, Hungary displayed characteristics of a 'pollution haven' in which foreign capital took advantage of the low regulatory level. These patterns clearly indicate a de facto 'stuck at the bottom' scenario triggered by pressures from regulatory competition. Notwithstanding strict standards on paper, their nonmandatory nature and inappropriate implementation tools indicate very weak regulatory requirements for potential investors, hence supporting hypothesis 1 . 


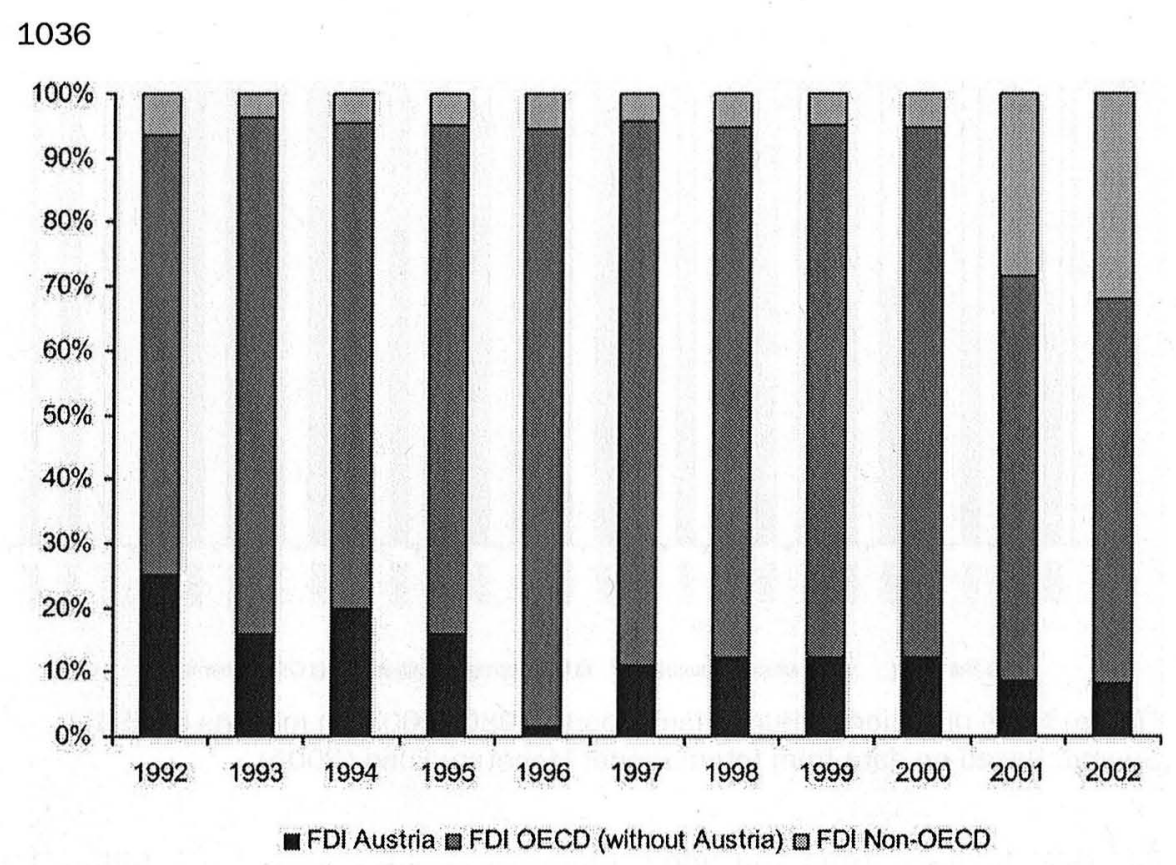

Figure 4 Foreign direct investment, net inflows 1992-2002 (in millions of forint) Source: Based on data from OECD International Direct Investment Statistics Yearbook (1997).

Stage 3: Strict regulation and differentiated implementation: conditionality and competition

Substantial adjustments to the existing regulatory approach only took place after Hungary achieved official status as an EU applicant in 1998. The revised regulation of industrial discharges into surface water entailed a new regulatory approach, transforming the former fine based limit values into truly obligatory ones. Sector-specific emission standards for 40 parameters were introduced with Decrees 203/2001 and 9/2001, now renewed as Decrees 220/2004 and 28/2004. General values that differ according to water classes were set whenever technical limit values are not applicable (interview $\mathrm{H} 2$ ).

Strong conditionality pressures emerged from an interim report of the European Commission in 2000 which found that Hungary was lagging behind the provisions of the environmental acquis. The country quickly passed the necessary new regulations to fill the gap and closed the environmental negotiations chapter in 2001 (Mocsári 2004: 189ff.; interview H4). In 2004, Hungary was almost 100 per cent compliant with EU environmental laws, disregarding agreed transition periods (interview $\mathrm{H} 4$ ).

Although for the four policy items under investigation no harmonization of standards took place at the EU level, several adjustments to the existing 
Hungarian legislation were required as a result of indirect effects emerging from related EU policies: the Directive on Dangerous Substances (76/464 EEC), the Directive on Integrated Pollution Prevention and Control (1996/ 91 EEC) and the Water Framework Directive 2000/60/EC. The directives prescribe that pollution reduction must be achieved via the application of the 'best available technology' (BAT). This requirement narrows the margin to fix concrete effluent standards for the member states (H4). Interestingly, however, Hungary, when introducing its set of new EU-compatible waste water standards, exceeded these EU specifications by emulating the more stringent German system rather than regulations from a member state at a comparable level of development, such as Portugal or Greece. 'We started with elaboration of these technological limit values ... taking the German system as a basis. [The new regulation] is in harmony with the German system'

(interview $\mathrm{H} 4$ ).

Hence, Hungary responded to conditionality pressures by introducing a much stricter policy copied from its major trading partner, a phenomenon hence supporting hypothesis 2 .

Regarding the implementation of the new scheme, there is evidence to support the expectation of persistent implementation deficits, as stated in hypothesis 3. Although since EU accession administrative efforts were initiated to improve implementation of the new decrees (interviews H4; H6), it is still questionable whether EU membership and compliance pressure actually improved the enforcement of environmental legislation in general, as well as the new decrees on industrial discharges into surface water. There is evidence that lax enforcement of water legislation is still quite common: 'those standards are not enforced' (interview H5; see also interviews H2; H3). Moreover, there are still hints about differentiated implementation. During the 1990s it was already somehow the 'unofficial policy' of the water and environmental administrations to treat domestic enterprises (typically using outdated technologies) and multinational companies differently. While the Regional Water Authorities or Regional Environmental Inspectorates insisted that large newly established industrial settlements were only granted a permit if they fulfilled all obligations, there was hardly similar pressure on existing domestic industries which should have been given time to adjust (interview H1). 'It was not [an] official policy ... but the Hungarian authorities tried ... that new firms meet the environmental standards ... Old firms [were given] transition [time]' (interview H1; see also $\mathrm{H} 5$ ). On the other hand, this practice seems to continue as (at least major) international investors are obliged to conform to current legislation immediately (interviews $\mathrm{H} 3$; $\mathrm{H} 7$; $\mathrm{H} 8$ ).

While Hungary strengthened its regulation in light of EU conditionality pressures, it still seeks to benefit from the comparative advantage of insufficient enforcement practice - at least with respect to technologically backward enterprises that are unable or unwilling to invest in pollution abatement or cleaner technologies. 


\section{COMPARATIVE ASSESSMENT AND CONCLUSIONS}

In this paper we argue that low-regulating countries which strive for international economic integration are confronted with the need to balance two contradictory challenges. On the one hand, low-regulating countries face strong pressure from regulatory competition which should induce them to keep weak environmental standards in order to protect the competitive position of their industries. On the other hand, the options for relying on this stuck at the bottom scenario are severely restricted, as high-regulating countries (for similar economic reasons) will generally make market integration conditional on the adoption of stricter regulations in low-regulating countries, seeking to avoid the emergence of pollution havens. To analyse how low-regulating countries cope with these challenges, we compared the development and enforcement of environmental standards in Hungary and Mexico.

When comparing the developments in both countries under investigation, several patterns can be identified. First, we see that neither Hungary nor Mexico experienced a stuck at the bottom scenario as a result of increasing economic interdependence. Both countries strengthened their regulatory arrangements.

Second, in both countries regulatory competition as well as conditionality pressures were important for setting the standards. In this context, it has to be emphasized that regulatory competition mattered, especially with regard to the protection of domestic industries. In both countries differentiated enforcement has been used to protect these industries. While domestic companies could rely on weak enforcement practice, the application of respective standards was much stricter for multinational companies. This practice of differentiated enforcement supports our hypothesis that regulatory competition is effective during the implementation of standards.

Turning to conditionality pressures, Mexican motivation to tighten its environmental legislation was clearly triggered by political opposition in the US to the country's NAFTA accession. In the case of Hungary, conditionality pressures worked more indirectly as there was no EU harmonization for the policies under study. Nevertheless, these indirect effects proved strong enough to trigger respective policy adjustments.

Finally, both countries seemed to balance pressures from regulatory competition and conditionality by combining stricter standards with lax or at least differentiated enforcement. Even if it is hard to prove finally that governments actually intended to apply this sort of strategy, there is no evidence of decisive attempts to reduce far-reaching enforcement deficits and increase respective administrative capacities.

Biographical notes: Christoph Knill is Professor of Political and Administrative Science at the University of Konstanz, Germany. Jale Tosun is a Junior Research Fellow in the Department of Politics and Management at the University of Konstanz, Germany. Stephan Heichel is a Junior Research Fellow in the Department of Politics and Management at the University of Konstanz, Germany. 
Address for correspondence: Christoph Knill, Department of Politics and Management, University of Konstanz, Box D 91, 74857 Konstanz, Germany. email: C.Knill@uni-konsanz.de

\section{NOTES}

1 The 18 interviews (ten in Mexico and eight in Hungary) were conducted in February and March 2005. Owing to space restrictions, we cannot provide a full list here, but see: www.uni-konstanz.de/FuF/Verwiss/knill/projekte/envipolcon/ project-homepage.php.

2 These changes have to be seen against the backdrop of a general modernization of environmental regulation, based on significant amendments to LGEEPA in 1996.

\section{REFERENCES}

Andor, L. (2000) Hungary on the Road to the European Union, Westport, CT/London: Praeger.

Araya, M. (2002) 'Mexico's NAFTA trauma: myth and reality', in C.L. Deere and D.C. Esty (eds), Greening the Americas - NAFTA's Lessons for Hemispheric Trade, Cambridge, MA/London: MIT Press, pp. 61-78.

Auer, M. (2001) 'Energy and environmental politics in post-corporatist Mexico', Policy Studies Journal 29(3): 437-55.

Dasgupta, S., Hettige, H. and Wheeler, D. (2000) 'What improves environmental compliance? Evidence from Mexican industry', Journal of Environmental Economics and Management 39: 39-66.

DiMaggio, P.J. and Powell, W.W. (1991) 'The iron cage revisited. Institutionalized isomorphism and collective rationality in organizational fields', in W.W. Powell and P.J. DiMaggio (eds.), The New Institutionalism in Organizational Analysis, Chicago: University of Chicago Press, pp. 63-82.

Drezner, D.W. (2005) 'Globalization, harmonization, and competition: the different pathways to policy convergence', Journal of European Public Policy 12(5): 841-59.

Enyedi, G. and Szirmai, V. (1998) 'Environmental movements and civil society in Hungary', in A. Tickle and I. Welsh (eds.), Environment and Society in Eastern Europe, Harlow: Longman, pp. 146-55.

Esty, D.C. and Geradin, D. (2001) 'Regulatory co-opetition', in D.C. Esty and D. Geradin (eds.), Regulatory Competition and Economic Integration: Comparative Perspectives, Oxford: Oxford University Press.

Hock, B. and Somlyódy, L. (1989) 'Water quality in Hungarian rivers', in H. Laikari (ed.), River Basin Management V: Proceedings of an IAWPRC Conference beld in Rovaniemi, Finland, 31 July-4 August 1989, Oxford: Pergamon Press, pp. 19-27.

Holzinger, K. and Knill, C. (2005) 'Causes and conditions of cross-national policy convergence', Journal of European Public Policy 12(5): 775-96.

Husted, B.W. and Logsdon, J.M. (1997) 'The impact of NAFTA on Mexico's environmental policy', Growth and Change 28(1): 24-48.

Jänicke, M. (1998) 'Umweltpolitik: Global am Ende oder am Ende global?', in U. Beck (ed.), Perspektiven der Weltgesellschaft, Frankfurt am Main: Suhrkamp, pp. 332-44.

Jiménez, B., Ramos, J. and Quezada, L. (1999) 'Analysis of water quality criteria in Mexico', Water Science and Technology 40(10): 169-75.

Kern, K. (2000) Die Diffusion von Politikinnovationen. Umweltpolitische Innovationen im Mehrebenensystem der USA, Opladen: Leske + Budrich.

Mall, B. (1998) 'The effect of NAFTA's environmental provisions on Mexican and Chilean policy', The International Lawyer 32: 153-87. 
Máttar, J., Moreno-Brid, J.C. and Peres, W. (2002) 'Foreign investment in Mexico after economic reforms', Serie Estudios y Perspectivas 10: 1-45.

Mocsári, J. (2004) 'Environmental policy in Hungary', in A. Ágh (ed.), Europeanization and Regionalization: Hungary's Preparation for EU Accession, Budapest: Hungarian Centre for Democracy Studies, pp. 173-230.

Murphy, D.D. (2004) The Structure of Regulatory Competition: Corporations and Public Policies in a Global Economy, Oxford: Oxford University Press.

OECD (1992) Economic Survey Mexico, Paris: OECD.

OECD (1998) Environmental Performance Review of Mexico, Paris: OECD.

OECD (2004) Economic Survey Hungary, Paris: OECD.

Porter, G. (1999) 'Trade competition and pollution standards: "race to the bottom" or "stuck at the bottom", Journal of Environment and Development 8(2): 133-51.

Przeworksi, A. and Teune, H. (1970) The Logic of Comparative Social Inquiry, New York: John Wiley \& Sons.

Richardson, J. (1995) 'EU water policy: uncertain agendas, shifting networks and complex coalitions', in H. Bressers, L.J. O’Toole Jr. and J. Richardson (eds.), Networks for Water Policy, London: Frank Cass, pp. 139-67.

Rueda, A. (2000) 'Tuna, dolphins, shrimp and turtles: what about environmental embargoes under NAFTA?', Georgetown International Environmental Law Review 12(3): 647-92.

Scheierling, S.M. (1998) 'Toward improved water quality management in Central and Eastern Europe', Water Resources Development 14(1): 5-24.

Tortajada, C. (2003) 'Policy failures prevent water quality progress in Mexico', Women and Water International (Wङ WI), May: 25-8.

Vogel, D. (2000) 'Environmental regulation and economic integration', Journal of International Economic Law 3(2): 265-79.

World Bank (1999) Hungary: On the Road to the European Union, Washington, DC: World Bank. 